June 1992

\title{
Reversal of Catatonia with Midazolam
}

Larry V. McDonald, M.D.

University of Kansas Medical Center

Barry I. Liskow, M.D.

University of Kansas School of Medicine

Follow this and additional works at: https://jdc.jefferson.edu/jeffjpsychiatry

Part of the Psychiatry Commons

Let us know how access to this document benefits you

\section{Recommended Citation}

McDonald, M.D., Larry V. and Liskow, M.D., Barry I. (1992) "Reversal of Catatonia with Midazolam,"

Jefferson Journal of Psychiatry. Vol. 10 : Iss. 2 , Article 10.

DOI: https://doi.org/10.29046/JJP.010.2.013

Available at: https://jdc.jefferson.edu/jeffjpsychiatry/vol10/iss2/10

This Article is brought to you for free and open access by the Jefferson Digital Commons. The Jefferson Digital Commons is a service of Thomas Jefferson University's Center for Teaching and Learning (CTL). The Commons is a showcase for Jefferson books and journals, peer-reviewed scholarly publications, unique historical collections from the University archives, and teaching tools. The Jefferson Digital Commons allows researchers and interested readers anywhere in the world to learn about and keep up to date with Jefferson scholarship. This article has been accepted for inclusion in Jefferson Journal of Psychiatry by an authorized administrator of the Jefferson Digital Commons. For more information, please contact: JeffersonDigitalCommons@jefferson.edu. 


\section{Brief Report}

\section{Reversal of Catatonia with Midazolam}

We report a case of dramatic reversal of catatonic symptoms with a single dose of midazolam, an ultra short acting parenteral benzodiazepine commonly used for procedure sedation.

Mr. S. is a 50 year old Caucasian male admitted to the Kansas City VA Medical Center with a six week history of depressive symptoms culminating in a suicide attempt. He was initially placed on nortriptyline $75 \mathrm{mg}$ PO daily with some improvement noted. Upon return from a pass one week after admission the patient appeared confused and disoriented. A urine drug screen was negative and CT scan without contrast was normal on the following morning. Over the next several days the patient became increasingly agitated and disoriented, refusing all food and fluids, roaming aimlessly around his room, and speaking in a totally incoherent manner. The patient also complained of intermittent generalized abdominal pain without evidence of vomiting or diarrhea. Except for his altered mental status, his physical and neurological exams were within normal limits. Because of increased agitation and confusion, four-point restraints and IV fluids were initiated. Except for elevation of WBC to 16,000 , initial laboratory evaluation including electrolytes, glucose, BUN, creatine, SGOT, SGPT, blood ammonia, a Schwartz-Watson test, abdominal x-rays and CSF exam was normal. Because of continued altered mental status, a second CT scan with contrast was performed three days later, at which time midazolam $2 \mathrm{mg}$ and meperidine $50 \mathrm{mg}$ were given IM for sedation. His symptoms of confusion and disorientation completely cleared within 20 minutes of medication administration. He remained coherent and oriented over the next three hours, and lorazepam $2 \mathrm{mg}$ PO every four hours was started. Careful review of his past medical records revealed a similar episode of disorientation following a major depressive episode four years prior to the current admission. Based upon clinical history, presenting symptoms, lab and pharmacological findings, the diagnosis of bipolar disorder with catatonia was made. He was placed on lithium $600 \mathrm{mg}$ PO BID and lorazepam was continued at a dose of $2 \mathrm{mg}$ PO QID for seventeen days until clonazepam $0.5 \mathrm{mg}$ PO QID was started for tapering purposes. During the tapering process, he experienced a brief recurrence of confusion and disorientation which was readily reversed by slowing the rate of clonazepam taper. Clonazepam taper was completed ten days after discharge from the hospital. He has remained symptom free during a nine (9) month period of follow-up.

In recent years, benzodiazepines have been used with increasing frequency for reversal of catatonia. Possible pharmacologic mechanisms of this action have been proposed based upon clinical observations and data gathered from animal experimentation (1).

Previously described use of 5-10 mg midazolam IM/IV in a patient with 
catatonic schizophrenia resulted in only brief periods of reversal lasting 15 minutes (2). We were able to obtain complete catatonic reversal lasting several hours utilizing less than half the dose of midazolam. No adverse effects occurred from use of this medication in our patient.

Our experience and the literature indicates that the threshold dose of benzodiazepines needed for catatonia reversal may vary greatly in patients with similar clinical presentations. Given the large numbers of psychiatric and nonpsychiatric conditions (3) in which catatonia may occur, we believe that midazolam, based upon its short half life, rapid onset of action, and highly specific CNS activity, should be considered a potentially useful therapeutic tool and may prove of value as a diagnostic aid.

Larry V. McDonald, M.D.

PGY-IV

Barry I. Liskow, M.D.

Professor and Acting Chair

Department of Psychiatry

University of Kansas Medical Center

\section{REFERENCES}

1. Menza M, Harris D: Benzodiazepines and Catatonia: An Overview. Biological Psychiatry 1989; 26:842-846

2. Delisle J: Catatonia Unexpectedly Reversed by Midazolam (letter). Am J Psychiatry 1991; 148:809

3. Gelenberg A: The Catatonic Syndrome. Lancet 1:1339-1341 